\title{
Seedling Parameters as Influenced by Seed Treatment in Sarpagandha (Rauvolfia serpentina Benth.)
}

\author{
Rahul S. Phatak", N.K. Hegde, P.M. Gangadharappa and Laxminarayan Hegde \\ KRC College of Horticulture, Arabhavi - 591 218, Karnataka, India \\ *Corresponding author
}

\begin{abstract}
A B S T R A C T
Keywords

Seed treatment,

Sarpagandha,

Rauvolfia

serpentina

Article Info

Accepted:

20 December 2017

Available Online:

10 January 2018

The experiment was carried out to know the effect of different seed treatments on seedling growth parameters in sarpagandha. The experiment was laid out in completely randomized design with seven treatments, replicated thrice. Among the different seed treatments tested, $\mathrm{GA}_{3}(1000$ $\mathrm{mg} \mathrm{L}^{-1}$ ) treatment was found to be the best, recording earliness to reach four leaf stage, highest values for shoot and root length $(10.99$ and $7.06 \mathrm{~cm}$, respectively) and vigour index (901.91). The $\mathrm{GA}_{3}$ treatment resulted in 39.06 per cent reduction in number of days to reach four leaf stage, 74.44 per cent increased shoot length, 15.93 per cent increased root length and 561.03 per cent increased vigour index over the control.
\end{abstract}

\section{Introduction}

Rauvolfia serpentina (L.) Benth. Ex. Kurz., commonly known as sarpagandha is an indigenous medicinal herb of Indian subcontinent, mentioned in ancient Indian medicinal literature, 3000 years back. It belongs to Apocynaceae family and the name Rauvolfia is assigned to the genus in honour of a German physician - Leonhart Rauvolf. Among 170 species found, Rauvolfia serpentina $(2 \mathrm{n}=22)$ is the chief, commercial source of important alkaloids. The roots of this plant have been used in the indigenous system of medicine. The roots are being used in the treatment of snake bite, insect stings, nervous disorders and psoriasis. It is also used in Ayurveda, Unani, Homeopathy and Siddha systems of medicines for the treatment of high blood pressure, insomnia, cardiac diseases and a number of mental problems such as psychic disorders, mental retardation, epilepsy, agitation and neurotic disorders, asthma, hypochondriasis, certain forms of insanity, acute stomach ache and painful delivery. Apart from traditional use in health care and culture it has been increasingly used in pharmaceutical industries. 'Serpasil' tablet for high blood pressure is prepared from roots. About 30 alkaloids are known to exist in this plant and the total alkaloid content ranges from 1.7 to 3 per cent of dried roots. The most 
important alkaloids are reserpine, serpentine, ajmaline, ajmalicin, rauvolfinine, recinamine and deserpidine. Continuous exploitation of sarpagandha from forests without taking proper care of its regeneration has resulted in decline in wild populations, rendered it to a vulnerable and threatened state, particularly in India (Farooqi and Sreeramu, 2001). Indiscriminate harvesting, loss of habitat, human and bio-interference, over-exploitation, etc. pose further serious threat to its wild resources. In view of the increasing demand for good quality material and need for conservation of natural resources, it has become necessary to develop proper agrotechnology for its domestication and cultivation on scientific lines. The seed propagated crop is known to give good quality material and higher yield but, seed germination is very poor in sarpagandha. It is reported to vary from 5 to 30 per cent even when only heavy seeds are chosen for sowing, though the seeds appear to be perfectly normal externally (Farooqui and Sreeramu, 2001). Hence, it is necessary to improve the seed germination in sarpagandha.

\section{Materials and Methods}

The experiment was conducted at KRC College of Horticulture, Arabhavi, Gokak (Tq.) Belagavi (Dist.), Karnataka during October - December, 2015, to test the effect of different seed treatments on germination in sarpagandha. The seeds were collected from the wild stand of sarpagandha plants found in the evergreen forests of Sirsi, Uttara Kannada (Dist.), Karnataka. The fruits collected from scattered plants found in the lower storey of evergreen forests were pulped manually to extract the seeds. Extracted seeds were washed in clean water and dried in shade. These seeds were subjected to floating test by immersing in water. The seeds which sink in water were selected for germination experiment.
The experiment comprised of seven treatments with three replications, laid out in Completely Randomized Design. The seeds were subjected to different treatments, $\mathrm{T}_{1}$ : overnight water soaking, $\mathrm{T}_{2}$ : overnight soaking of seeds in $\mathrm{GA}_{3}\left(1000 \mathrm{mg} \mathrm{l}^{-1}\right)$ solution, $\mathrm{T}_{3}$ : soaking seeds in concentrated $\mathrm{H}_{2} \mathrm{SO}_{4}$ for one minute, $\mathrm{T}_{4}$ : overnight soaking of seeds in $\mathrm{KNO}_{3}(1 \%)$ $+\mathrm{HNO}_{3}(1 \%)$ solution, $\mathrm{T}_{5}$ : overnight soaking in cow urine (collected on the previous day), $\mathrm{T}_{6}$ : overnight soaking of seeds in cow dung slurry (cow dung : water in 1:1 ratio) and $\mathrm{T}_{7}$ being the control (without any treatment). Hundred seeds were used for soaking in each of the treatments. The seeds after treatment were sown in protrays (of 50 wells), filled with coco peat and watered frequently based on necessity. The protrays were maintained in the indoor (ambient) condition in the laboratory.

\section{Results and Discussion}

\section{Days to four leaf stage}

The number of days to reach four leaf stage (Table 1) was significant due to seed treatments. The seedlings took minimum number of days to reach four leaf stage in $\mathrm{GA}_{3}$ (69.67) compared to rest of the treatments whereas, maximum was observed in control (114.33). Comparison of means of treatments indicated that, $\mathrm{GA}_{3}$ treatment lead to 39.04 per cent reduction in number of days taken to reach four leaf stage.

\section{Shoot length}

The data pertaining to the shoot length revealed the significant difference among the treatments (Table 1). The shoot length was maximum in $\mathrm{GA}_{3}$ treatment $(10.99 \mathrm{~cm})$. However, it was on par with $\mathrm{KNO}_{3}+\mathrm{HNO}_{3}$ treatment $(10.48 \mathrm{~cm})$ and cow dung slurry treatment $(9.32 \mathrm{~cm})$. The lowest shoot length was recorded in the control $(6.30 \mathrm{~cm})$. 
Table.1 Shoot length, root length and vigour index at four leaf stage, as influenced by seed treatment in sarpagandha

\begin{tabular}{|c|c|c|c|c|c|c|c|c|}
\hline \multirow[t]{2}{*}{ Treatment } & \multicolumn{2}{|c|}{ Days to 4- leaf stage } & \multicolumn{2}{|c|}{ Shoot length $(\mathrm{cm})$} & \multicolumn{2}{|c|}{ Root length (cm) } & \multicolumn{2}{|c|}{ Vigour index } \\
\hline & Mean & $\begin{array}{c}\text { Per cent } \\
\text { deviation* } \\
\text { (Earliness) }\end{array}$ & Mean & $\begin{array}{c}\text { Per cent } \\
\text { deviation* }\end{array}$ & Mean & $\begin{array}{c}\text { Per cent } \\
\text { deviation* }\end{array}$ & Mean & $\begin{array}{c}\text { Per cent } \\
\text { deviation* }\end{array}$ \\
\hline$T_{1}$ : Water soaking & 107.00 & 6.41 & 6.46 & 2.54 & 5.94 & -2.46 & 206.57 & 51.40 \\
\hline $\mathrm{T}_{2}: \mathrm{GA}_{3}\left(1000 \mathrm{mg} \mathrm{l}^{-1}\right)$ & 69.67 & 39.06 & 10.99 & 74.44 & 7.06 & +15.93 & 901.91 & 561.03 \\
\hline $\mathrm{T}_{3}$ : Conc. $\mathrm{H}_{2} \mathrm{SO}_{4}$ (for $1 \mathrm{~min}$.) & 90.00 & 21.28 & 7.71 & 22.38 & 5.32 & -12.64 & 260.94 & 91.25 \\
\hline $\mathrm{T}_{4}: \mathrm{KNO}_{3}+\mathrm{HNO}_{3}(1 \%$ each $)$ & 96.00 & 16.03 & 10.48 & 66.35 & 6.12 & +0.49 & 487.02 & 256.95 \\
\hline $\mathbf{T}_{5}$ : Cow urine treatment & 110.33 & 3.50 & 8.44 & 33.97 & 4.57 & -24.96 & 221.12 & 62.06 \\
\hline $\mathrm{T}_{6}$ : Cow dung treatment & 94.67 & 17.20 & 9.32 & 47.94 & 5.76 & -5.42 & 543.29 & 298.19 \\
\hline $\mathbf{T}_{7}:$ Control & 114.33 & - & 6.30 & - & 6.09 & - & 136.44 & - \\
\hline S.Em \pm & 1.46 & - & 0.24 & - & 0.17 & - & 14.18 & - \\
\hline C.D. at $1 \%$ & 6.19 & - & 1.01 & - & 0.72 & - & 59.69 & - \\
\hline CV (\%) & 2.61 & - & 4.87 & - & 5.06 & - & 6.23 & - \\
\hline
\end{tabular}

*Per cent deviation for the mean of respective treatment over control 
There was an increment of 74.44 and 66.35 per cent in shoot length in $\mathrm{GA}_{3}$ and $\mathrm{KNO}_{3}+\mathrm{HNO}_{3}$ treatment, respectively when compared to control.

\section{Root length}

The data on root length showed the significant difference among the treatments (Table 1). The significantly highest root length was recorded in $\mathrm{GA}_{3}$ treatment $(7.06 \mathrm{~cm})$ compared to rest of the treatments. The lowest root length was recorded in control $(4.57 \mathrm{~cm})$. There was an increased root length of 15.93 per cent in $\mathrm{GA}_{3}$ treatment over control.

\section{Vigour index}

The data pertaining to vigour index recorded significant difference among the treatments (Table 1). Among the seed treatments, significantly highest vigour index was recorded in $\mathrm{GA}_{3}$ (900.25). The lowest value for vigour index was seen in control (136.44). The vigour index in seed treatment with $\mathrm{GA}_{3}$ recorded 561.03 per cent increase over control.

There was significant difference among the treatments for seedling parameters viz., days to four leaf stage, shoot length, root length and vigour index (Table 1).

The number of days taken for attaining four leaves in germinated seedling was significantly lower in $\mathrm{GA}_{3}$ (69.67) compared to rest of the treatments. However, significantly higher number of days to attain four leaves was observed in control (107.00). Seed treatment with $\mathrm{GA}_{3}$ lead to 39.06 per cent reduction in number of days taken to reach four leaf stage.

The shoot length was maximum in $\mathrm{GA}_{3}$ treatment $(10.99 \mathrm{~cm})$ and it was on par with $\mathrm{KNO}_{3}+\mathrm{HNO}_{3}$ treatment $(10.48 \mathrm{~cm})$ and cow dung slurry treatment $(9.32 \mathrm{~cm})$. The lowest shoot length was recorded in the control (6.30 $\mathrm{cm})$. There was an increment of 74.44 and 66.35 per cent in shoot length in $\mathrm{GA}_{3}$ and $\mathrm{KNO}_{3}+\mathrm{HNO}_{3}$ treatment, respectively over control. Significantly highest root length was recorded in $\mathrm{GA}_{3}$ treatment $(7.06 \mathrm{~cm})$ compared to other treatments and the lowest was recorded in cow urine treatment (4.57 $\mathrm{cm})$. There was an increased root length of 15.93 per cent in $\mathrm{GA}_{3}$ treatment over control. As it is universally known that, $\mathrm{GA}_{3}$ helps in the cell elongation; the exogenous application of gibberellin might have enhanced the elongation of cells in a better way.

It might have helped in the faster growth of shoot and root as a result, the seedlings might have reached the four leaf stage earlier in seeds treated with $\mathrm{GA}_{3}$. The results are in accordance with Ponkumar et al., (2008) and Muneshwar (2015) in sarpagandha, Velmurugan et al., (2003) in ashwagandha and Joshi and Pant (2010) in Canna indica. Significantly higher vigour index was recorded in $\mathrm{GA}_{3}$ (901.91) compared to the lowest in control (136.44).

The vigour index in seed treatment with $\mathrm{GA}_{3}$ recorded 561.03 per cent increase over control. The increased vigour index might be attributed to increased shoot length, root length and germination percentage in seeds due to $\mathrm{GA}_{3}$ treatment (Table 1).

Among the different seed treatments tested in sarpagandha, $\mathrm{GA}_{3}\left(1000 \mathrm{mg} \mathrm{L}^{-1}\right)$ treatment was found to be the best, recording earliness in attaining four leaf stage, highest values for shoot and root length and vigour index. The $\mathrm{GA}_{3}$ treatment resulted in 39.03 per cent reduction in number of days to attain four leaf stage, 74.44 per cent increased shoot length, 15.93 per cent increased root length and 561.03 per cent increased vigour index over control. 


\section{References}

Farooqi, A. A. and Sreeramu, B. S., 2001. Cultivation of medicinal and aromatic crops. Universities press (India) Limited, pp234-241.

Joshi, S. C. and Pant, S. C., 2010. Effect of $\mathrm{H}_{2} \mathrm{SO}_{4}$ on seed germination and viability of Canna indica $\mathrm{L}$. a medicinal plant. J. American Sci., 6(6):24-25.

Muneshwar, B. R., 2015. Standardization of seed germination testing procedure in sarpagandha (Rauvolfia serpentina Benth.). M.Sc. (Agri.) Thesis, Mahatma
Phule Krishi Vidyapeeth, Rahuri, Maharashtra.

Ponkumar, P., Padma, M., Rajkumar, M. and Madulety, T. Y., 2008. Effect of chemicals and plant growth substances on breaking of seed dormancy in sarpagandha (Rauvolfia serpentina L.). J. Res. ANGRAU, 36(1):54-56.

Velmurugan, S., Vadivel, E. and Paramaguru, P., 2003. Studies on seed germination in Ashwagandha (Withania somnifera). In: Proc. Nat. Sem. New. Prespect. Sps. Med. Arom. Pl.

\section{How to cite this article:}

Rahul S. Phatak, N.K. Hegde, P.M. Gangadharappa and Laxminarayan Hegde. 2018. Seedling Parameters as Influenced by Seed Treatment in Sarpagandha (Rauvolfia serpentina Benth.). Int.J.Curr.Microbiol.App.Sci. 7(01): 2539-2543. doi: https://doi.org/10.20546/ijcmas.2018.701.305 